\title{
KOMENTARZ DO ZASAD OBLICZANIA PŁYT NA PRZEBICIE W STREFIE SŁUPÓW NAROŻNYCH WEDLUG EUROKODU 2
}

\begin{abstract}
W artykule omówiono zasady obliczania na przebicie płyt w strefie słupów narożnych. Omówiono cztery metody określania naprężeń stycznych, wynikających z działania momentu niezrównoważonego, przekazywanego z płyty na słup. Przedstawiono przykład liczbowy ilustrujący różnice w rozkładzie naprężeń stycznych na długości obwodu kontrolnego w zależności od zastosowanej procedury obliczeniowej. Dokonano porównania wyników obliczeń z rezultatami badań eksperymentalnych. Pokazano, iż w większości przypadków stosowanie zasad Eurokodu 2 prowadzi do wyników po stronie bezpiecznej, aczkolwiek rzeczywiste nośności zostały w wielu przypadkach znacznie niedoszacowane - w szczególności dotyczyło to obliczeń metodą ogólną. Najlepszą zgodność, przy zarazem satysfakcjonującym poziomie bezpieczeństwa obliczeń, uzyskano w przypadku zastosowania metody zredukowanych obwodów kontrolnych. Na podstawie przeprowadzonych analiz zalecono ponadto ograniczenie wartości współczynnika $k$, uwzględniającego udział mechanizmu przebicia w przekazywaniu momentu niezrównoważonego z płyty na słup.
\end{abstract}

Słowa kluczowe: przebicie, ustroje płytowo - słupowe, słupy narożne, Eurokod 2, moment niezrównoważony, naprężenia styczne

\section{Wprowadzenie}

Jedno z najbardziej newralgicznych miejsc w ustrojach płytowo - słupowych stanowią strefy podporowe, w których dochodzi do koncentracji sił wewnętrznych mogących doprowadzić do przebicia. W Eurokodzie 2 [7] precyzyjnie określono zasady obliczeń dotyczących przebicia $w$ strefie podpór wewnętrznych, kiedy mimośród obciążenia wynikający z działania momentów niezrównoważonych, przekazywanych z płyty na słup, jest stosunkowo niewielki. Zupełnie inna sytuacja ma natomiast miejsce w przypadku słupów narożnych.

\footnotetext{
${ }^{1}$ Autor do korespondencji / corresponding author: Michał Gołdyn, Politechnika Łódzka, Katedra Budownictwa Betonowego, al. Politechniki 6, 90-924 Łódź, tel. (42) 631-35-80, e-mail: michal.goldyn@p.lodz.pl

2 Tadeusz Urban, Politechnika Łódzka, Katedra Budownictwa Betonowego, al. Politechniki 6, 90-924 Łódź, tel. (42) 636-19-84, e-mail: tadeusz.urban@p.lodz.pl
} 
Ze względu na kształt połączenia, w typowych sytuacjach projektowych wypadkowy mimośród obciążenia $e$ wynosi około $0,75 \div 2,0 c$ (gdzie $c$ jest długością boku słupa). W ujęciu procedur obliczeniowych znacznemu zwiększeniu ulega wówczas wpływ niezrównoważonego momentu zginającego na rozkład naprężeń stycznych na obwodzie kontrolnym. Analiza przebicia w strefie słupów narożnych jest $\mathrm{w}$ przypadku stosowania metody ogólnej dość skomplikowana, dlatego też autorzy Eurokodu 2 umożliwili korzystanie z alternatywnych metod uproszczonych - zredukowanych obwodów kontrolnych oraz stałych współczynników $\beta$. Celem artykułu jest odpowiedź na pytanie, czy zasady dotyczące analizy przebicia w strefie słupów narożnych według Eurkodu 2 są bezpieczne, a także czy wszystkie proponowane podejścia obliczeniowe dają zbieżne rezultaty.

\section{Określanie naprężeń stycznych według Eurokodu 2}

W analizie przebicia według Eurokodu 2 [7] zakłada się plastyczny rozkład naprężeń stycznych na długości obwodu kontrolnego, nawiązujący do koncepcji Masta [5]. Przyjmuje się, iż całkowite naprężenia styczne stanowią superpozycję naprężeń wywołanych przebiciem osiowym $v_{E d}(V)$ (wywołanych działaniem siły poprzecznej $V_{E d}$ ) i mimośrodowym $v_{E d}(M)$ (wywołanym działaniem momentu niezrównoważonego $\Delta M_{E d}$ ) - patrz rys. 1. Wpływ drugiego składnika jest zależny od kształtu i położenia słupa oraz sztywności giętnej i skrętnej węzła płytowo - słupowego. W przypadku przebicia mimośrodowego maksymalne naprężenia styczne na długości obwodu kontrolnego opisane są następująco:

$$
v_{E d}=v_{E d, V}+v_{E d, M}=\beta \frac{V_{E d}}{u_{1} d}=\left(1+k \frac{\Delta M_{E d}}{V_{E d}} \frac{u_{1}}{W_{1}}\right) \frac{V_{E d}}{u_{1} d}
$$

gdzie: $\beta \quad$ - współczynnik zwiększający naprężenia styczne z uwagi na działanie momentu niezrównoważonego $\Delta M_{E d}$,

$V_{E d}$ - reakcja przekazywana z płyty stropowej na słup,

$\Delta M_{E d}$ - moment zginający przekazywany z płyty na słup,

$u_{1} \quad$ długość podstawowego obwodu kontrolnego (w odległości $2 d$ od krawędzi podpory),

$W_{1} \quad$ - wskaźnik podstawowego obwodu kontrolnego $u_{l}$,

$d \quad$ - średnia wysokość użyteczna płyty,

$k \quad-$ współczynnik wyrażający udział naprężeń stycznych (mechanizm przebicia) w przekazywaniu oddziaływania $\Delta M_{E d}$ na słup ; pozostała część $(1-k)$ momentu niezrównoważonego $\Delta M_{E d}$ jest przykazywana na słup poprzez zginanie i skręcanie, które wywołują w płycie naprężenia normalne i nie prowadzą do wzrostu naprężeń stycznych $v_{E d}$. 


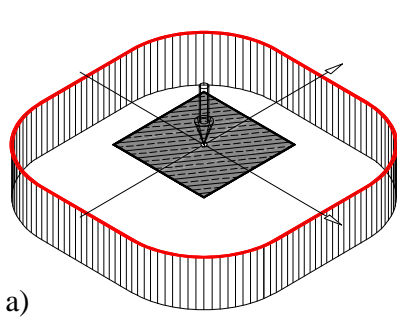

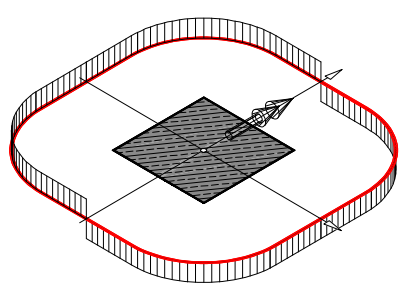

b)

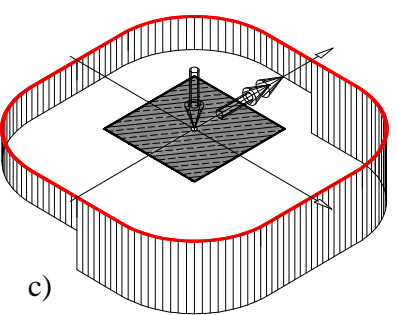

Rys. 1. Teoretyczny rozkład naprężeń stycznych na długości obwodu kontrolnego $u_{1}$ wokół słupa wewnętrznego, wywołanych działaniem: a) siły osiowej $V_{E d}$, b) niezrównoważonego momentu zginającego $\Delta M_{E d}$, c) obu wymienionych oddziaływań

Fig. 1. Theoretical distribution of shear stresses along control perimeter $u_{1}$, around internal column, resulted from: a) axial force $V_{E d}$, b) unbalanced bending moment $\Delta M_{E d}$, c) the combined action of the two aforementioned effects

W przypadku analizy przebicia płyt stropowych o nieregularnej siatce podpór a także gdy poprzeczna sztywność konstrukcji zależy głównie od współpracy płyt stropowych i słupów, należy korzystać z metody ogólnej, opisanej równaniem (1). Podejście to jest najbardziej czasochłonne i skomplikowane. Wymaga ustalenia wskaźnika $W_{1}$, liczonego względem osi działania wypadkowego momentu zginającego $\Delta M_{E d, n e t}$, przechodzącej jednocześnie przez środek ciężkości obwodu kontrolnego - patrz rys. 2a. $Z$ uwagi na złożoność kształtu obwodu kontrolnego najbardziej praktyczne wydaje się w tym przypadku skorzystanie z programu komputerowego typu CAD. Procedurę tę należy powtórzyć każdorazowo dla zestawów sił odpowiadających $\left(V_{E d}, M_{E d, y}, M_{E d, z}\right)$.
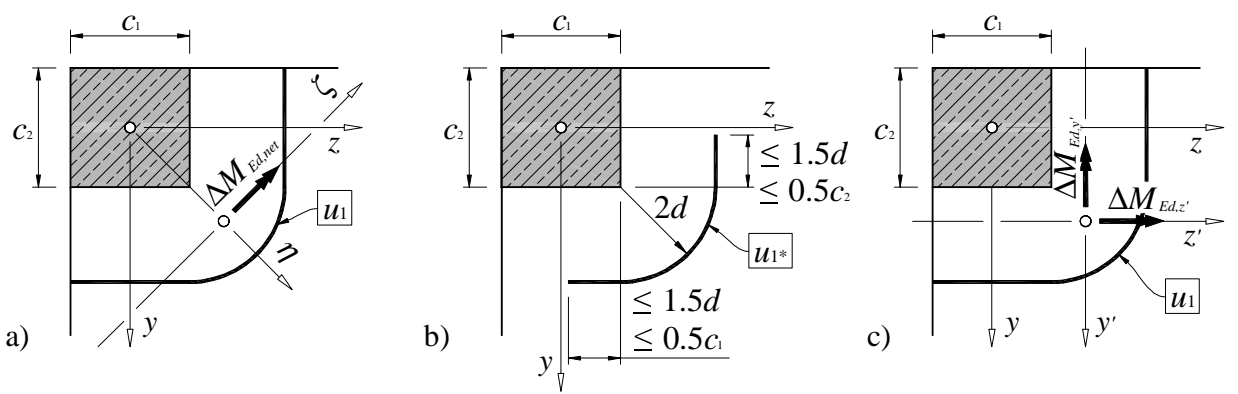

Rys. 2. Układy współrzędnych oraz obwody kontrolne uwzględnianie przy określaniu wpływu momentu niezrównoważonego w metodzie: a) ogólnej, b) obwodów zredukowanych, c) superpozycji wg [2]

Fig. 2. Coordinate systems and control perimeters considered by determining the effects of action of unbalanced moment according to: a) general method, b) method of reduced basic control perimeters, c) method of superposition by [2]

Autorzy normy, prawdopodobnie świadomi trudności, jakie stwarzać może korzystanie z metody ogólnej w przypadku analizy przebicia w strefie słupów 
krawędziowych i narożnych, zaproponowali dwie metody uproszczone. W pierwszej z nich, tzw. metodzie obwodów zredukowanych, zakłada się równomierny rozkład naprężeń stycznych, wywołanych łącznym działaniem siły przebijającej $V_{E d}$ i momentu niezrównoważonego $\Delta M_{E d}$, na długości zredukowanego obwodu kontrolnego $u_{1 *}$. Stanowi on fragment podstawowego obwodu kontrolnego $u_{1} \mathrm{~W}$ sąsiedztwie wewnętrznego naroża słupa - patrz rys. 2b. Naprężenia styczne określone są następująco:

$$
v_{E d}=\beta \frac{V_{E d}}{u_{1^{*}} d}=\frac{u_{1}}{u_{1^{*}}} \cdot \frac{V_{E d}}{u_{1^{*}} d}
$$

Druga $\mathrm{z}$ metod uproszczonych, tzw. metoda stałych współczynników $\beta$, może być stosowana jedynie w przypadku analizy konstrukcji nieprzesuwnych, o regularnej siatce podpór, gdy rozpiętości sąsiednich przęseł różnią się o nie więcej niż $25 \%$. Jest to najprostszy ze sposobów uwzględnia wpływu niezrównoważonego momentu zginającego - naprężenia wywołane przebiciem osiowym zwiększa się bowiem o pewną stałą wartość, równą w przypadku podpór narożnych $\beta=1,50$. Zdaniem Heggera i in. [4] stosowanie metod uproszczonych może prowadzić do wyników po stronie niebezpiecznej, dlatego też ich stosowanie zostało zakazane w normie niemieckiej DIN-EN 1992-1-1 [2]. W zamian zaproponowano alternatywny sposób określania współczynnika $\beta$, wprowadzając wyrażenie (6.39.1):

$$
\beta=1+\sqrt{\left(k_{y^{\prime}} \frac{\Delta M_{E d, y^{\prime}}}{V_{E d}} \frac{u_{1}}{W_{1, y^{\prime}}}\right)^{2}+\left(k_{z^{\prime}} \frac{\Delta M_{E d, z^{\prime}}}{V_{E d}} \frac{u_{1}}{W_{1, z^{\prime}}}\right)^{2}}
$$

Stosowane oznaczenia są analogiczne jak w wyrażeniu (1), przy czym wielkości $k_{i}, \Delta M_{E d, i}$ oraz $W_{1, i}$ należy ustalać względem obu osi, równoległych do swobodnych krawędzi płyty i przechodzących przez środek ciężkości obwodu kontrolnego $u_{1}$ - patrz rys. 2c. Podejście DIN-EN 1992-1-1 [2] zakłada superpozycję efektów oddziaływań momentów zginających $M_{\mathrm{y}}$ oraz $M_{z}$, działających względem osi równoległych do obu krawędzi płyty. Taki sposób analizy ściśle nawiązuje do postanowień amerykańskich ACI 318-14 [1], w których naprężenia styczne na długości obwodu kontrolnego, położonego w odległości $0,5 d$ od krawędzi słupa, opisano następującą funkcją:

$$
v_{u}=\frac{V_{u}}{A_{c}} \pm \gamma_{v y} \frac{M_{u y} \cdot z}{J_{y}} \pm \gamma_{v z} \frac{M_{u z} \cdot y}{J_{z}}
$$

gdzie: $V_{E d}$ - reakcja przekazywana z płyty stropowej na słup,

$A_{c} \quad$ - pole powierzchni przekroju kontrolnego, 
$M_{u i} \quad$ - momenty zginające działające względem osi równoległych do krawędzi płyty, przechodzących przez środek ciężkości obwodu kontrolnego,

$y, z \quad$ - odległości punktów położonych na obwodzie kontrolnym od osi działania momentów zginających - odpowiednio $M_{u z}$ oraz $M_{u y}$,

$J_{y}, J_{z}$ - cechy geometryczne obwodu kontrolnego, analogiczne do momentów bezwładności, liczonych względem osi działania momentów zginających,

$\gamma_{v i} \quad$ - współczynniki uwzględniające udział naprężeń stycznych (mechanizm przebicia) w przekazywaniu niezrównoważonego momentu zginającego na słup.

Podstawowa różnica polega jednak na tym, iż norma amerykańska ACI 318-14 [1] zakłada liniowy rozkład naprężeń stycznych, podczas gdy w Eurokodzie 2 [7] operuje się rozkładem plastycznym. Stosowanie superpozycji jest wówczas pozbawione sensu fizycznego i zdaniem autorów nieuprawnione. Może bowiem prowadzić do przekłamań przy określaniu rozkładu naprężeń stycznych. Wskutek działania momentów niezrównoważonych naprężenia styczne powinny ulegać zmniejszeniu w miarę zbliżania się do krawędzi płyty, natomiast wartość maksymalną powinny osiągać w sąsiedztwie wewnętrznego naroża słupa. Na rysunku 3. pokazano naprężenia styczne określone zgodnie z zasadami Eurokodu 2 [7] oraz ACI 318-14 [1] (w obu przypadkach przyjęto obwody kontrolne w odległości $2 d$ od krawędzi słupa).

a)
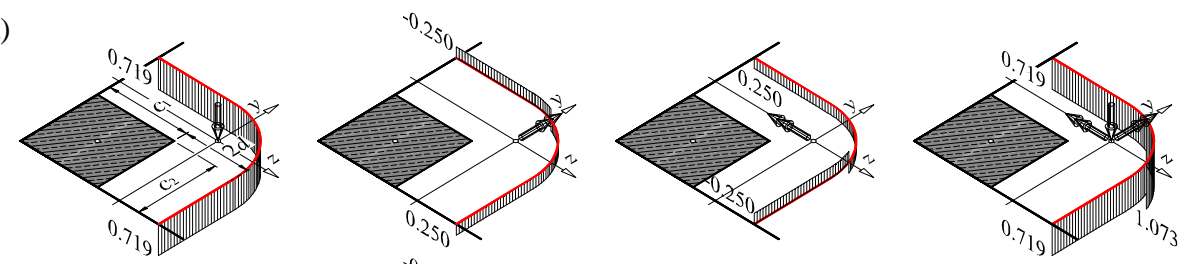

b)
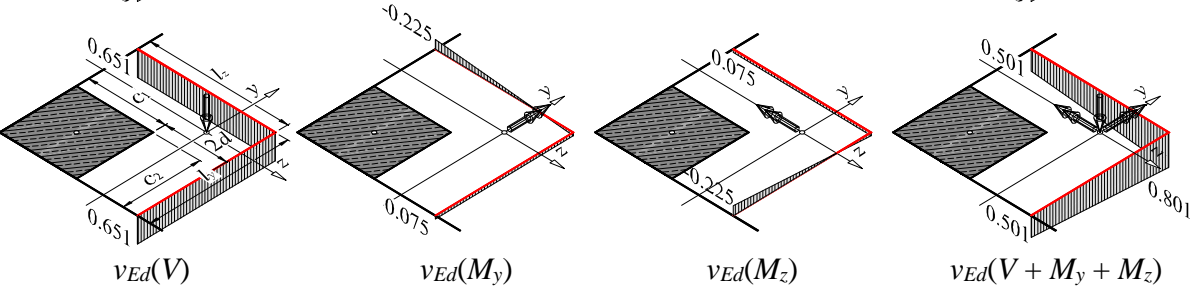

Rys. 3. Naprężenia styczne wynikające z działania: siły poprzecznej $V$, momentu zginającego $M_{y}$, momentu zginającego $M_{z}$, łącznego działania wspomnianych sił, określone według: a) DIN-EN 1992-1-1 [2], b) procedury nawiązującej do zasad ACI 318-14 [1]

Fig. 3. Shear stresses resulted from acting of: shear force $\mathrm{V}$, bending moment My, bending moment $\mathrm{My}, \mathrm{c})$ the combined action of the aforementioned effects, according to: a) DIN-EN 1992-1-1 [2], b) procedure referring to principles of ACI 318-14 [1] 
Stosowanie reguł DIN-EN 1992-1-1 [2] prowadzi jedynie do zwiększenia naprężeń stycznych w sąsiedztwie wewnętrznego naroża słupa. Współczynnik zwiększający naprężenia styczne $\mathrm{z}$ uwagi na działanie momentu niezrównoważonego $1,073 / 0,719=1,49$ jest przy tym o około $20 \%$ wyższy od ustalonego według procedury nawiązującej do ACI 318-14 $(0,801 / 0,651=1,23)$.

\section{Porównanie procedur obliczeniowych}

Wszystkie przedstawione procedury określania naprężeń wywołanych przebiciem mimośrodowym powinny oczywiście dawać wynik zbieżny. Chociaż można się było spodziewać się, że wyniki obliczeń metodami uproszczonymi będą większe od ustalonych metodą ogólną. W celu porównania wspomnianych metod obliczeniowych rozważono płytę $\mathrm{w}$ strefie słupa narożnego o przekroju kwadratowym ( $c=400 \mathrm{~mm}$ ), połączonego z płytą o grubości $200 \mathrm{~mm}(d=160 \mathrm{~mm})$. Przyjęto następujące reakcje: $V_{E d}=150,0 \mathrm{kN}, M_{E d, c o l, y}=M_{E d, c o l, z}=65,0 \mathrm{kNm}$. Uzyskane rozkłady naprężeń stycznych pokazano na rys. 4 . Na podstawie obliczeń metodą ogólną i metodą zredukowanych obwodów kontrolnych otrzymano podobne wartości naprężeń maksymalnych, a także zbliżony rozkład naprężeń stycznych (koncentracja w strefie wewnętrznego naroża słupa). Podobnie naprężenia styczne określone metodą stałych współczynników $\beta$ oraz według propozycji DIN-EN 1992-1-1 [2] okazały się bardzo zbliżone, jednak mniejsze aż o około $30 \%$ od wartości ustalonych zgodnie $\mathrm{z}$ dwiema pierwszymi procedurami. Widoczna jest w tym przypadku także znaczna różnica w rozkładzie naprężeń. W przypadku metody stałych współczynników $\beta$ naprężenie minimalne na krawędzi płyty stanowiło 33\% wartości maksymalnej, podczas gdy zgodnie z procedurą niemiecką wynosiło $67 \%$ wartości maksymalnej. Sugeruje to znacznie mniejszy wpływ momentu niezrównoważonego na rozkład naprężeń stycznych niż wynikałoby to $\mathrm{z}$ analiz prowadzonych zgodnie z pozostałymi procedurami - por. rys. $4 \mathrm{a} \div \mathrm{c}$.
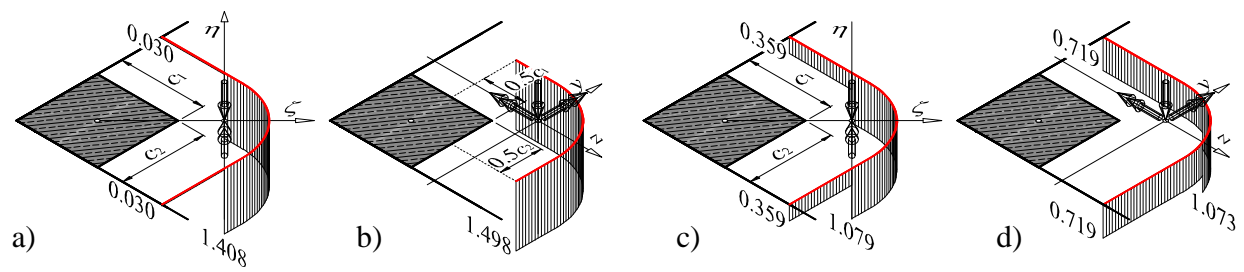

Rys. 4. Rozkład naprężeń stycznych ustalonych zgodnie z procedurami Eurokodu 2: a) metodą ogólną, b) metodą zredukowanych obwodów kontrolnych, c) metodą stałych współczynników $\beta$, d) metodą superpozycji wg [2]

Fig. 4. Distribution of shear stresses determined according to Eurocode 2 principles: a) general method, b) method of reduced basic control perimeters, c) method of constant $\beta$ factors, c) method of superposition by [2] 


\section{Procedury normowe w świetle wyników badań}

Znaczne rozbieżności pomiędzy wynikami obliczeń stanowiły przesłankę do porównania procedur obliczeniowych z wynikami badań eksperymentalnych, dotyczących przebicia płyt w strefie słupów narożnych. Ze względu na znaczną trudność zbadania takich modeli, w literaturze dostępnych jest stosunkowo niewiele wyników badań. W analizie skorzystano z rezultatów prac Walkera i Regana [9] oraz Zaghloola i de Paivy [10]. Charakterystykę modeli badawczych zamieszczono w Tablicy 1.

Tabela 1. Charakterystyka modeli rozważanych w badaniach [9] oraz [10]

Table 1. Characteristics of specimens considered in investigations [9] and [10]

\begin{tabular}{|c|c|c|c|c|c|c|c|c|c|}
\hline \multicolumn{2}{|c|}{ Model } & $\begin{array}{c}c \\
{[\mathrm{~mm}]}\end{array}$ & $\begin{array}{c}d \\
{[\mathrm{~mm}]}\end{array}$ & $\begin{array}{c}f_{c m} \\
{\left[\mathbf{N} / \mathbf{m m}^{2}\right]}\end{array}$ & $\begin{array}{c}\rho_{l} \\
{[\%]}\end{array}$ & $\begin{array}{l}V_{e x p} \\
{[\mathbf{k N}]}\end{array}$ & $\begin{array}{c}M_{\text {exp }} \\
{[\mathrm{kNm}]}\end{array}$ & $\begin{array}{c}e \\
{[\mathrm{~mm}]}\end{array}$ & $\begin{array}{l}e / c \\
{[-]}\end{array}$ \\
\hline \multirow{7}{*}{ 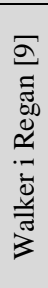 } & $\mathrm{SC} 1$ & 300 & 100 & 43,3 & 0,65 & 81,5 & 35,6 & 437 & 1,458 \\
\hline & $\mathrm{SC} 2$ & 300 & 100 & 47,9 & 0,42 & 74,8 & 33,9 & 454 & 1,513 \\
\hline & $\mathrm{SC} 3$ & 300 & 100 & 37,4 & 0,84 & 74,2 & 44,7 & 602 & 2,008 \\
\hline & $\mathrm{SC} 4$ & 220 & 100 & 40,8 & 0,65 & 63,8 & 23,6 & 370 & 1,683 \\
\hline & SC5 & 220 & 100 & 46,5 & 0,93 & 82,2 & 26,6 & 323 & 1,470 \\
\hline & SC6 & 220 & 100 & 45,5 & 0,00 & 79,0 & 35,9 & 455 & 2,067 \\
\hline & SC7 & 220 & 100 & 43,8 & 0,93 & 82,2 & 39,0 & 475 & 2,158 \\
\hline \multirow{7}{*}{ 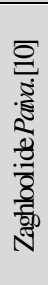 } & Z-I(1) & 178 & 120 & 32,7 & 1,23 & 74,3 & 27,1 & 365 & 2,052 \\
\hline & Z-II(1) & 267 & 120 & 33,0 & 1,23 & 137,9 & 54,5 & 395 & 1,480 \\
\hline & Z-II(2) & 267 & 120 & 33,4 & 1,65 & 177,2 & 75,6 & 426 & 1,597 \\
\hline & Z-II(3) & 267 & 120 & 27,7 & 2,23 & 177,9 & 82,1 & 461 & 1,727 \\
\hline & Z-II(6) & 267 & 120 & 33,6 & 1,23 & 82,3 & 55,1 & 669 & 2,506 \\
\hline & Z-II(8) & 267 & 120 & 36,1 & 1,23 & 139,0 & 54,6 & 393 & 1,470 \\
\hline & Z-III(1) & 356 & 120 & 33,6 & 1,23 & 179,7 & 74,6 & 415 & 1,166 \\
\hline
\end{tabular}

$c$ - szerokość słupa, $d$ - wysokość użyteczna, $f_{c m}$ - średnia wytrzymałość betonu płyty na ściskanie, $\rho_{l}$ - średni stopień zbrojenia podłużnego płyty, $V_{e x p}$ - maksymalne obciążenie płyty, $M_{\exp }$ - maksymalny moment niezrównoważony związany z obciążeniem $V_{\exp }, e$ - mimośród obciążenia płyty

Teoretyczną nośność odpowiadającą przebiciu osiowemu określono zgodnie z zasadami Eurokodu 2 [7]:

$$
V_{R}=v_{R, c} \cdot u d=\max \left\{\begin{array}{l}
0,18 k \sqrt[3]{100 \rho_{l} f_{c m}} \cdot u d \\
0,035 \sqrt{k^{3} f_{c m}}
\end{array}\right.
$$

gdzie: $k \quad$ - współczynnik uwzględniający efekt skali: $k=1+(200 / d)^{0,5} \leq 2,0$,

$\rho_{l} \quad$ - średni stopień zbrojenia podłużnego płyty,

$f_{c m}$ - średnia wytrzymałość betonu płyty na ściskanie,

$u$ - długość obwodu kontrolnego ( $u_{1}$ lub $u_{1^{*}}$, zależnie od metody obliczeń),

$d \quad$ - średnia wysokość użyteczna płyty. 
W celu uwzględnienia wpływu działania niezrównoważonego momentu zginającego, nośność przy przebiciu osiowym $V_{R}$ redukowano za pomocą współczynnika $\beta$, określonego zgodnie z przedstawionymi wcześniej procedurami obliczeń. Na rysunku 5. pokazano zależność pomiędzy rzeczywistymi nośnościami modeli $V_{\text {exp }}$ a wartościami teoretycznymi $V_{\text {calc }}$, ustalonymi zgodnie z zasadami Eurokodu 2, w zależności od względnego mimośrodu obciążenia e/c.
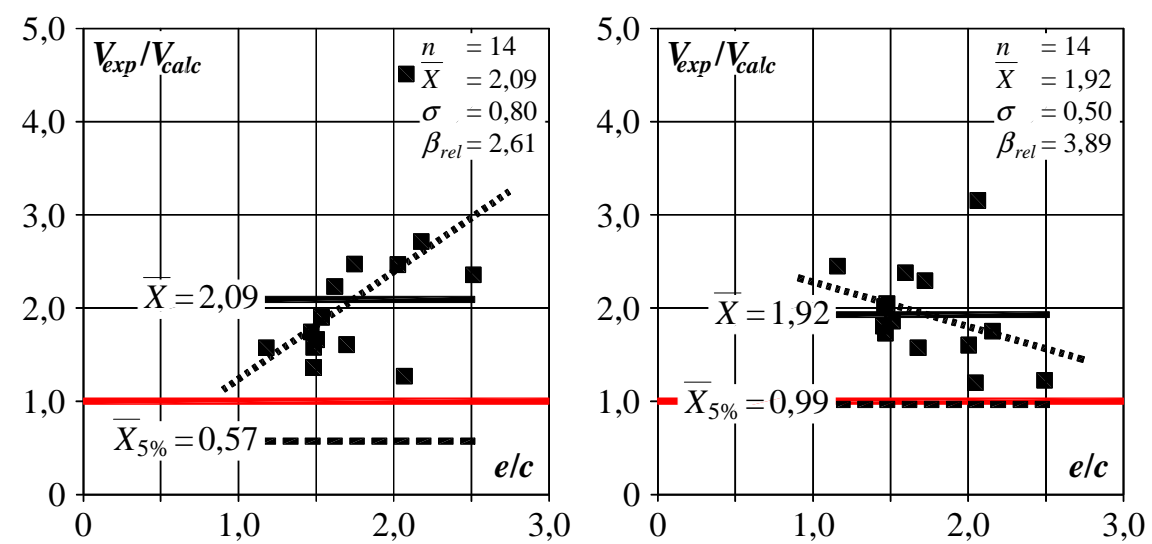

a)

b)
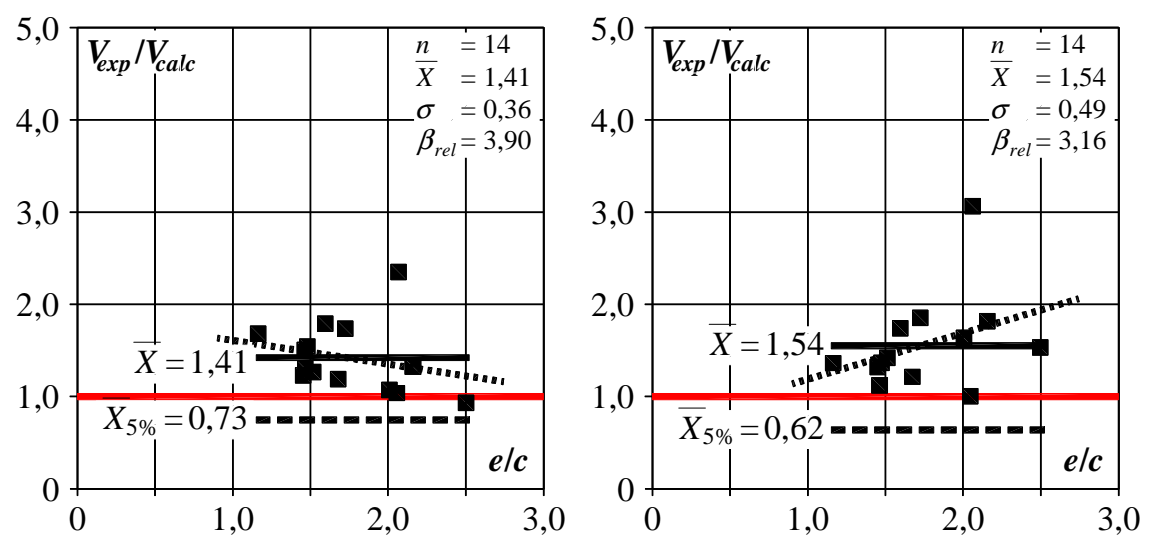

c)

d)

Rys. 5. Porównanie nośności eksperymentalnych $V_{\exp }$ i teoretycznych $V_{\text {calc }}$ w zależności od względnego mimośrodu $e / c$ i przyjętej metody obliczeń: a) metoda ogólna, b) metoda obwodów zredukowanych, c) metoda stałych współczynników $\beta$, d) metoda superpozycji wg DIN-EN 1992-1-1 [2]

Fig. 5. Comparison between experimental $V_{\text {exp }}$ and theoretical $V_{\text {calc }}$ load carrying capacities depending on relative eccentricity $e / c$ and adopted method of calculation: a) general method, b) method of reduced basic control perimeters, c) method of constant $\beta$ factors, c) method of superposition by [2] 
Każda z rozpatrywanych procedur pozwoliła przewidzieć nośność modeli w sposób bezpieczny, jednak w wielu przypadkach wyniki okazały się znacznie niedoszacowane. W szczególności dotyczyło to metody ogólnej, uzyskano bowiem średni stosunek $V_{\text {exp }} / V_{\text {calc }}=2,09$, przy współczynniku zmienności $\alpha=38 \%$ $\mathrm{W}$ przypadku pozostałych metod wielkości statystyczne kształtowały się następująco:

- metoda obwodów zredukowanych: $V_{\text {exp }} / V_{\text {calc }}=1,92, \alpha=26 \%$,

- metoda stałych współczynników $\beta: \quad V_{\text {exp }} / V_{\text {calc }}=1,41, \alpha=26 \%$,

- metoda superpozycji wg DIN-EN 1992-1-1 [2]: $V_{\text {exp }} / V_{\text {calc }}=1,54, \alpha=32 \%$.

$\mathrm{W}$ celu oceny poziomu bezpieczeństwa poszczególnych metod wyznaczono także wartości charakterystyczne stosunku nośność eksperymentalnej do teoretycznej $X_{5 \%}$ - patrz rys. 5. Jedynie w przypadku metody obwodów zredukowanych wartość $X_{5 \%}$ była bliska jedności, co oznacza, iż procedurę tę można byłoby uznać za bezpieczną. W przypadku metody ogólnej, ze względu na znaczne rozproszenie wyników, wartość $X_{5 \%}$ okazała się bardzo niska, równa zaledwie 0,57 . W przypadku metod uproszczonych (patrz rys. $5 \mathrm{~b}$ i c) obserwuje się spadek poziomu bezpieczeństwa, wyrażonego ilorazem $V_{\text {exp }} / V_{\text {calc }}$, wraz ze wzrostem względnego mimośrodu $e / c$. Warto przy tym wspomnieć, iż poziom bezpieczeństwa wynikający z zapisów Eurokodu 0 [6] (klasa niezawodności RC2, okres odniesienia 50 lat), reprezentowany przez minimalną wartość współczynnika niezawodności $\beta_{\text {rel,min }}=3,8$, osiągnięto jedynie w przypadku obliczeń metodami uproszczonymi - patrz rys. 5 .
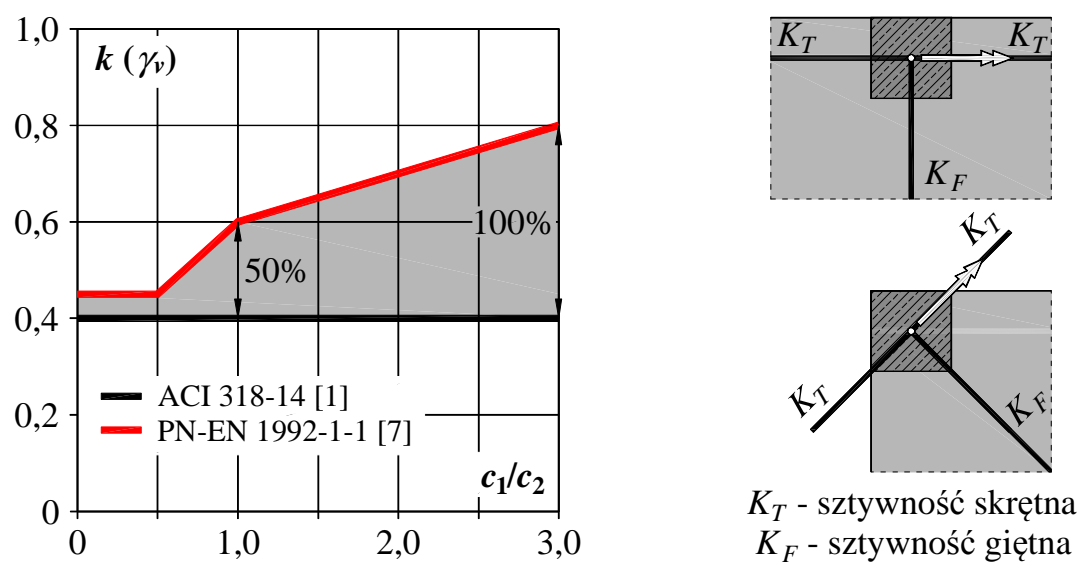

Rys. 6. Współczynniki wyrażające udział me- Rys. 7. Porównanie sztywności giętnych i skrętchanizmu przebicia w przekazywaniu momentu nych złączy krawędziowych i narożnych zginającego na słup

Fig. 6. Coefficients representing contribution of Fig. 7. Comparison of flexural and torsional punching shear mechanism in transfer of unbal- stiffnesses of edge and corner column-slab conanced bending moment to column nection joints 
Przyczyny znacznej dysproporcji pomiędzy wynikami badań i rezultatami obliczeń metodą ogólną należy upatrywać w wartości parametru $k$, uwzględniającego udział naprężeń stycznych w przekazywaniu momentu zginającego na słup. W Eurokodzie 2 [7], podobnie jak i w normie amerykańskiej ACI 318-14 [1] (współczynnik $\gamma_{v}$ ) parametr ten uzależniono wyłącznie od proporcji boków słupa $c_{1} / c_{2}$ - patrz rys. 6 . Norma amerykańska zakłada mniejszy udział mechanizmu przebicia w przekazywaniu momentu na słup - w odniesieniu do przekroju kwadratowego aż o $50 \%$.

Jak pokazały wyniki analizy Urbana [8] udział ten może być jednak nadal przeszacowany, co przemawiałoby za obniżeniem wartości współczynnika $\gamma_{v}$ poniżej wartości 0,4. Zarówno autorzy pracy [3] jak i Eurokodu 2 [7] przyjęli jednakowe wartości współczynników rozdziału momentu zginającego w odniesieniu do połączeń krawędziowych i narożnych. Takiemu rozumowaniu przeczy jednak kształt obu rodzajów połączeń. W przeciwieństwie do połączeń krawędziowych, w przypadku połączeń narożnych niemal nie występują elementy ze sztywnością skrętną, co powinno znaleźć odzwierciedlenie w różnych wartościach współczynników $k$ i $\gamma_{v}$-patrz rys. 7. Zaghlool $\mathrm{i}$ in. [11] stwierdzili znikomy wpływ skręcania na rozkład naprężeń stycznych w strefie podpór narożnych i pominęli wpływ tego czynnika w proponowanej, empirycznej metodzie obliczeniowej.

Biorąc pod uwagę powyższe rozważania, przeanalizowano powtórnie obliczenia metodą ogólną, zakładając jednocześnie dwukrotnie mniejszy udział mechanizmu ścinania w przekazywaniu momentu niezrównoważonego na słup (tj. $k=0,3)$. Uzyskano średni stosunek nośności eksperymentalnej do teoretycznej $V_{\text {exp }} / V_{\text {calc }}=1,52$ przy współczynniku zmienności $\alpha=32 \%$ i współczynniku niezawodności $\beta_{r e l}=3,13$.

\section{Wnioski}

Przeprowadzana analiza porównawcza pokazała, iż procedury Eurokodu 2 [7] $\mathrm{z}$ reguły pozwalają opisać nośność na przebicie w strefie podpór narożnych w sposób bezpieczny. Otrzymane wyniki cechowało jednak duże rozproszenie, dlatego też akceptowalny poziom bezpieczeństwa uzyskano jedynie w przypadku procedur uproszczonych: metody stałych współczynników $\beta$ oraz obwodów zredukowanych. Trzeba zauważyć, że ostatnia z metod wymaga stosunkowo niewielkiego nakładu pracy, pozwoliła najlepiej opisać wyniki badań, zaś wartość charakterystyczna stosunku nośności eksperymentalnej do teoretycznej $X_{5 \%}$ okazała się bliska jedności. Autorzy referatu zalecają, by w przypadku metody ogólnej rozważyć ograniczenie wartości współczynnika $k$, uwzględniającego udział mechanizmu przebicia w przekazywaniu momentu niezrównoważonego z płyty na słup. Przyjmowanie takich samych wartości w odniesieniu do połączeń wewnętrznych, krawędziowych i narożnych nie jest zasadne z uwagi na różną sztywność wspomnianych węzłów. W przypadku połączeń narożnych prowadzi to do przeszacowania wartości współczynników $\beta$ i tym samym znacznego zaniżenia rzeczywistej nośności przy przebiciu mimośrodowym. 


\title{
Literatura
}

[1] ACI 318-14 Building Code Requirements for Structural Concrete, Commentary on Building Code Requirements, American Concrete Institute, Farmington Hills (2015).

[2]DIN EN 1992-1-1/NA:2011-01 Nationaler Anhang - National festgelegte Parameter - Eurocode 2: Bemessung und Konstruktion von Stahlbeton- und Spannbetontragwerken - Teil 1-1, Deutsches Institut für Normung, Januar 2011.

[3]Elgabry A.A., Ghali A.: Transfer of Moment between Columns and Slabs: Proposed Code Revisions, ACI Structural Journal, Vol. 93, N. 1 (January-February 1996), ss. 56-61.

[4]Hegger J., Häusler F., Ricker M.: Zur Durchstanzbemessung von ausmittig beanspruchten Stützenknoten und Einzelfundamenten nach Eurocode 2, Beton- und Stahlbetonbau, H. 11 (2008), ss. 723-734.

[5] Mast P. E.: Stresses in Flat Plates Near Columns, ACI Journal, Proceedings 67 (1970), N. 10, ss. 761-768.

[6]PN-EN 1990 Eurokod 0 - Podstawy projektowania konstrukcji, Polski Komitet Normalizacyjny, Warszawa, 2004.

[7]PN-EN 1992-1-1 Eurokod 2 - Projektowanie konstrukcji z betonu - Część 1-1: Reguły ogólne i reguły dla budynków, Polski Komitet Normalizacyjny, Warszawa 2008.

[8] Urban T.S.: Przebicie w żelbecie : wybrane zagadnienia, Zeszyty Naukowe - Politechnika Łódzka, Rozprawy Naukowe, Z. 344, 2005, ss. 257-260.

[9] Walker P.R., Regan P. E.: Corner Column - Slab Connections in Concrete Flat Plates, Journal of Structural Engineering, Vol. 113, Issue 4 (April 1987), ss. 704-720.

[10]Zaghlool E.R.F., de Paiva H.A.R.: Strength Analysis of Corner Column-Slab Connections, Journal of the Structural Division, Vol. 99, Issue 1, (1973), ss. 53-70.

[11]Zaghlool E.R.F., de Paiva H.A.R., Glockner P.G.: Tests of Reinforced Concrete Flat Plate Floors, Journal of the Structural Division, Vol. 96, Issue 3, (1970), ss. 487-507.

\section{COMMENTARY TO PRINCIPLES OF EUROCODE 2 CONCERNING PUNCHING SHEAR OF FLAT SLABS WITHIN CORNER COLUMNS}

\begin{abstract}
S u m m a r y
The paper presents the provisions for punching shear within corner columns. Four methods of determining of shear stresses, resulting from acting of unbalanced moment, were discussed. An example showing the differences in shear stress distribution on the control perimeter, depending on the design method, was presented. Experimental and theoretical results were also presented and discussed. It has been shown that in most cases the application of the principles of Eurocode 2 leads to results on the safe side although very conservative. The best agreement with experimental results was obtained by applying the method of reduced control perimeters.
\end{abstract}

Keywords: punching shear, column - slab structures, corner columns, Eurocode 2, unbalanced moment, shear stresses

Przestano do redakcji: 20.05.2017 $r$.

Przyjęto do druku: 01.09.2017 r. 